\section{Screening for steatorrhoea with an oxalate loading test}

The tedium and unpleasantness of collecting faeces to measure the excretion of fat have provoked a search for other ways of screening for steatorrhoea. Malabsorption of fat is associated with hyperoxaluria due to enhanced intestinal absorption of oxalate, ${ }^{1-3}$ which has led to measurement of 24 hour urinary oxalate excretion after an oral oxalate load being used as a screening test for steatorrhoea ${ }^{4}{ }^{5}$ In the test of Andersson and Gillberg the oral load was given as spinach, ${ }^{4}$ but the availability of oxalate from this source varies. ${ }^{5}$ Our earlier test required the patient to take a defined diet for a week as well as a three day sodium oxalate load. ${ }^{5}$ We now describe a similar test simplified by the abolition of dietary restriction and by the administration of sodium oxalate for only two days.

\section{Patients, methods, and results}

We studied 50 patients aged 18-84 with suspected malabsorption of fat, six of whom were outpatients. They were all taking an unrestricted diet and were given $300 \mathrm{mg}$ sodium oxalate daily in gelatin capsules dissolved in $200 \mathrm{ml}$ of water with lunch and supper for two days. On the second day a 24 hour urine specimen was collected and over days 1-3 a three day faecal specimen was collected. Urinary oxalate (using the oxalate decarboxylase method), urinary creatinine, and faecal fat excretions were measured as described previously 5 Patients with known colonic or renal disease were prospectively excluded from the study, and others were retrospectively excluded because of incomplete collection of urine as indicated by urinary creatinine excretion $<6 \mathrm{mmol}(679 \mathrm{mg}) / 24 \mathrm{~h}$ (17 patients); failure to take the oxalate capsules (one patient); or deficient collection of faecal specimens ( $<65 \mathrm{~g}$ in three days) (14 patients)

The figure shows the excretion of urinary oxalate and faecal fat and the final diagnoses in the 50 patients studied. Of the 25 patients with steatorrhoea

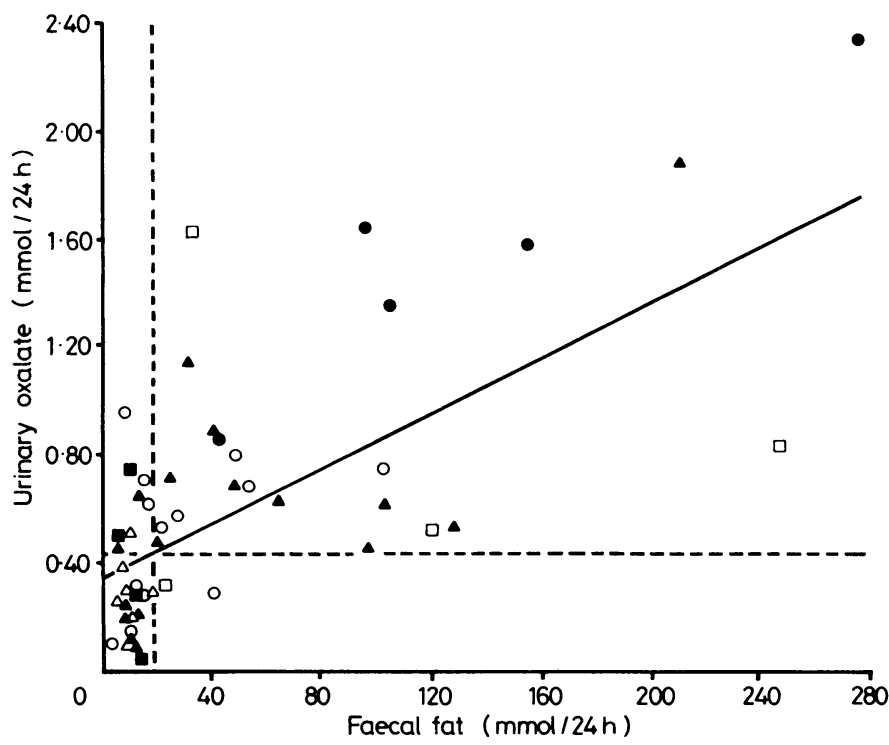

Twenty four hour urinary oxalate and faecal fat excretions in $\mathbf{5 0}$ patients with: Crohn's disease $(O)$; jejunoileal bypass $(O)$; pancreatic insufficiency $(\square)$; recurrent acute pancreatitis $(\boldsymbol{\Xi})$; irritable bowel syndrome $(\Delta)$; or other diagnoses $(\boldsymbol{\Delta})$ (after gastrectomy (3), after vagotomy (1), small-bowel resection (2), small-bowel contamination (2), coeliac disease (2), radiation enteritis (1), treatment with mefenamic acid (2), food intolerance (1), and hepatic cirrhosis (3))

Dotted lines indicate upper limits of excretion in normal subjects.

Conversion: SI to traditional units-Oxalate: $1 \mathrm{mmol} / 24 \mathrm{~h} \approx 90 \mathrm{mg} / 24 \mathrm{~h}$. Fat: $1 \mathrm{mmol} / 24 \mathrm{~h}=284 \mathrm{mg} / 24 \mathrm{~h}$.

(median faecal fat excretion $52 \mathrm{mmol} / 24 \mathrm{~h}(14.8 \mathrm{~g} / 24 \mathrm{~h})$; range $20-276 \mathrm{mmol}$ / $24 \mathrm{~h}(5 \cdot 7-78 \mathrm{~g} / 24 \mathrm{~h})$ ), 23 had hyperoxaluria (median urinary oxalate excretion $0.73 \mathrm{mmol} / 24 \mathrm{~h}(92 \mathrm{mg} / 24 \mathrm{~h})$; range $0.28-2.35 \mathrm{mmol} / 24 \mathrm{~h}(35-296 \mathrm{mg} / 24 \mathrm{~h})$; normal $<0.44 \mathrm{mmol} / 24 \mathrm{~h}(56 \mathrm{mg} / 24 \mathrm{~h}))$ and two gave false negative results due to pancreatic insufficiency and Crohn's disease. Urinary oxalate excretion was significantly lower in the 25 patients without steatorrhoea (median urinary oxalate excretion $0.31 \mathrm{mmol} / 24 \mathrm{~h}(39 \mathrm{mg} / 24 \mathrm{~h})$; range $0.05-0.95 \mathrm{mmol} / 24 \mathrm{~h}$ $(6-120 \mathrm{mg} / 24 \mathrm{~h}))(\mathrm{p}<0.002$, Wilcoxon's two tailed rank sum test). False positive results (urinary oxalate excretion $>0.44 \mathrm{mmol} / 24 \mathrm{~h}(56 \mathrm{mg} / 24 \mathrm{~h}$ )) occurred in three patients with terminal ileal Crohn's disease or resection of the ileum, or both, two with cirrhosis, two with recurrent acute pancreatitis, and one with the irritable bowel syndrome. The predictive value of normal urinary oxalate excretion for normal faecal fat excretion was $89 \%$, and that of hyperoxaluria for steatorrhoea $74 \%$.

\section{Comment}

The simplified oxalate loading test identified all but two of the 25 patients with steatorrhoea. The false negative results may have been due to consumption of a high calcium diet, ${ }^{2}$ failure to take the sodium oxalate load, incomplete urine collection, or occult colonic disease. ${ }^{3}$ Possible explanations of the eight false positive results include a diet containing excess oxalate ${ }^{2}$ consumption of the oxalate load other than with a meal, ${ }^{1}$ incomplete collection of faeces, primary hyperoxaluria, and malabsorption of bile acid due to terminal disease or resection of the ileum. ${ }^{3}$

The modified oxalate loading test is a convenient screening procedure for steatorrhoea. In patients with hyperoxaluria malabsorption of fat requires formal confirmation and oxalate urolithiasis should also be considered. Patients who prove not to have steatorrhoea may have malabsorption of bile acids. In patients with normal urinary oxalate excretion, however, faecal collection may be rendered entirely unnecessary.

We thank Mr A R Williams and the pharmacy staff of this hospital for supplying the sodium oxalate capsules.

${ }^{1}$ Chadwick VS, Modha K, Dowling RH. Mechanism of hyperoxaluria in patients with ileal dysfunction. $N$ Engl f Med 1973;289:172-6.

${ }^{2}$ Earnest DL, Johnson G, Williams HE, Admirand WH. Hyperoxaluria in patients with ileal resection: an abnormality in dietary oxalate absorption. Gastroenterology 1974;66:1114-22.

3 Dobbins JW, Binder HJ. Importance of the colon in enteric hyperoxaluria. $N$ Engl f Med 1977;296:298-301.

4 Andersson $\mathrm{H}$, Gillberg R. Urinary oxalate on a high oxalate diet as a clinical test of malabsorption. Lancet 1977 ;ii:677-9.

5 Rampton DS, Kasidas GP, Rose GA, Sarner M. Oxalate loading test: a screening test for steatorrhoea. Gut 1979;20:1089-94.

(Accepted 14 February 1984)

University College Hospital, London WC1E 6AU

D S RAMPTON, DPHIL, MRCP, clinical lecturer, department of medicine A D MCCULLOUGH, BSC, MD, registrar, department of chemical pathology JOLANTA S SABBAT, MB, BS, senior house officer, department of chemical pathology

J R SALISBURY, BSC, MB, senior house officer, department of chemical pathology

F V FLYNN, MD, FRCPATH, professor of chemical pathology

M SARNER, MD, FRCP, consultant physician, department of gastroenterology Correspondence to: Dr $M$ Sarner.

\section{Testicular carcinoma in situ in children with the androgen insensitivity (testicular feminisation) syndrome}

Patients with the androgen insensitivity syndrome show a predisposition to germ cell tumours in the adult testis. ${ }^{1}$ In other groups at risk of germ cell malignancies, such as patients with maldescent of the testes, the tumour may be preceded by carcinoma in situ many years before there is overt evidence of neoplasm. ${ }^{23}$ We therefore investigated whether carcinomatous changes could be seen in children with the androgen insensitivity syndrome.

\section{Patients, methods, and results}

We studied 12 consecutive patients with the androgen insensitivity syndrome (median age 6 years (range 2 months to 19 years)). All had $46, X Y$ karyotype and a female phenotype. Four had complete and eight incomplete androgen insensitivity syndrome. In all cases gonadal tissue was removed for prophylactic or diagnostic reasons rather than because a tumour had formed. Samples of testicular tissue were obtained from 20 boys after sudden unexpected death ${ }^{4}$ who were matched for age and served as controls. 